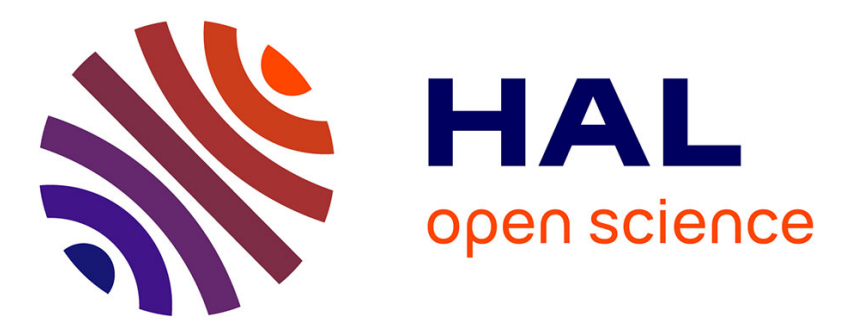

\title{
Synthesis of Nitrogen- and Oxygen-Containing Heterocycles by Prins Cyclization in Continuous Flow
}

Armando Talavera-Alemán, Jérome Marrot, Guillaume Dagousset, Christine Thomassigny

\section{- To cite this version:}

Armando Talavera-Alemán, Jérome Marrot, Guillaume Dagousset, Christine Thomassigny. Synthesis of Nitrogen- and Oxygen-Containing Heterocycles by Prins Cyclization in Continuous Flow. Synthesis: Journal of Synthetic Organic Chemistry, 2021, 53 (8), pp.1478-1488. 10.1055/s-0040-1705988 . hal03125948

\section{HAL Id: hal-03125948 \\ https://hal.science/hal-03125948}

Submitted on 15 Oct 2021

HAL is a multi-disciplinary open access archive for the deposit and dissemination of scientific research documents, whether they are published or not. The documents may come from teaching and research institutions in France or abroad, or from public or private research centers.
L'archive ouverte pluridisciplinaire HAL, est destinée au dépôt et à la diffusion de documents scientifiques de niveau recherche, publiés ou non, émanant des établissements d'enseignement et de recherche français ou étrangers, des laboratoires publics ou privés. 


\section{Synthesis of nitrogen and oxygen containing heterocycles by Prins cyclization in continuous flow}

\author{
Armando Talavera-Alemán* \\ Jérome Marrot \\ Guillaume Dagousset* \\ Christine Thomassigny*
}

ILV-UMR CNRS 8180, Université de Versailles-St-Quentin-enYvelines, 45 avenue des Etats-Unis, 78035 Versailles Cedex, France.

armando.talavera.uvsq.fr, guillaume.dagousset@uvsq.fr, christine.thomassigny@uvsq.fr

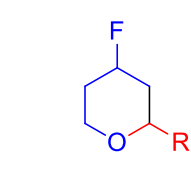

7 examples syn/anti up to $1: 6$ yield up to $59 \%$

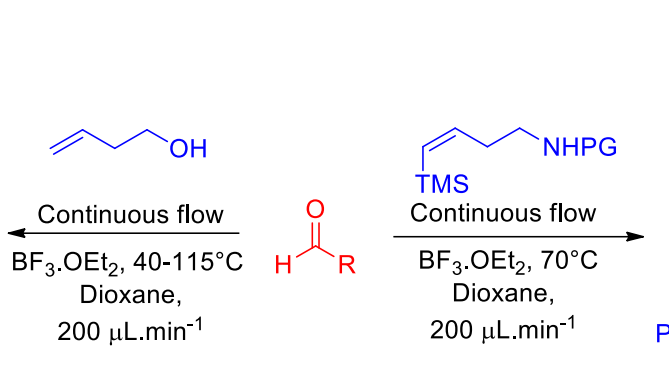

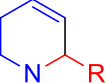

$\stackrel{\prime}{P G}$

8 examples yield up to $90 \%$

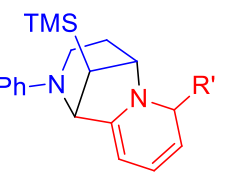

two examples $51-70 \%$

Abstract Aza-silyl-Prins and oxa-Prins cyclization reactions in continuous flow chemistry are described for the synthesis of the corresponding tetrahydropyridines and pyran derivatives, respectively. In particular, the use of pyridine-carboxaldehydes for aza-silyl-Prins reaction led to a symmetrical triarylmethane or two new bicyclic compounds. 4-fluorinated2-substituted tetrahydropyran derivatives were also obtained in the oxaPrins cyclization with good selectivity in favor of the anti isomer

Key words Aza-silyl-Prins - Oxa-Prins - Continuous flow chemistry • Tetrahydropyridine $\bullet$ dihydropyran

Six-membered heterocycles containing oxygen, nitrogen or sulfur atoms represent an important moiety in natural products or biologically active compounds. Prins-type cyclization is an interesting approach for carbon-heteroatom and carbon-carbon bonds formation in the way to synthesize these structures. ${ }^{1}$ This reaction involves the condensation between an aldehyde and a homoallylic alcohol, amine, or thiol, mediated by a Lewis ${ }^{2}$ or Brønsted ${ }^{3}$ acid, which can also act as reactant providing a nucleophile. The choice of the homoallylic partner is determinant for the structure of product obtained: for example, a non-substituted homoallylic derivative, gives a saturated six-membered heterocycle with a substituent at C-4 (Scheme 1a) ${ }^{1 a, 4}$ while a silyl-substituted homoallylic derivative leads to a heterocycle with a double bond in position C-3/C-4 (Scheme 1b). ${ }^{5}$ Different methodologies, such as the use of ionic liquids, ${ }^{6}$ microwave assistance ${ }^{7}$ and more recently Vibrational Strong Coupling (VSC), ${ }^{8}$ have been applied in the study of Prins-type cyclization reactions.

In this context, continuous flow chemistry has become an important technique in organic synthesis due to many advantages. Indeed, the high surface-to-volume ratio enables an optimal control of heating. Mixing is also improved compared to batch conditions, which leads to cleaner and

faster reactions. In addition, a better control of the key reaction parameters enables good reproducibility as well as easy scaleup of the reactions. Finally, the high surface area allows for a good control of exotherms, and potential hazardous intermediates are only formed in small amounts, which improves the process safety compared to classical batch reactors. ${ }^{9}$ Continuous flow chemistry has been used in the synthesis of $\mathrm{N}$-containing heterocycles, such as pyridine, ${ }^{10}$ quinolone, ${ }^{11}$ pyrrolidine and pyrrole derivatives, ${ }^{12}$ as well as oxygen-containing ones, like pyran ${ }^{13}$ and furan derivatives. ${ }^{14}$ Despite the large number of studies about the Prins cyclization, there are no reports on the continuous flow conditions to synthesize six-membered heterocycles by this reaction. We proposed that flow chemistry could overcome some problems classically encountered with Prins reaction in batch, namely the presence of undesirable byproducts, and the sometimes moderate yields. Additionally, we aimed to study the stereochemistry of the reaction under flow conditions. We report herein the synthesis of tetrahydropyridine and pyran derivatives by Prins cyclization under flow conditions.

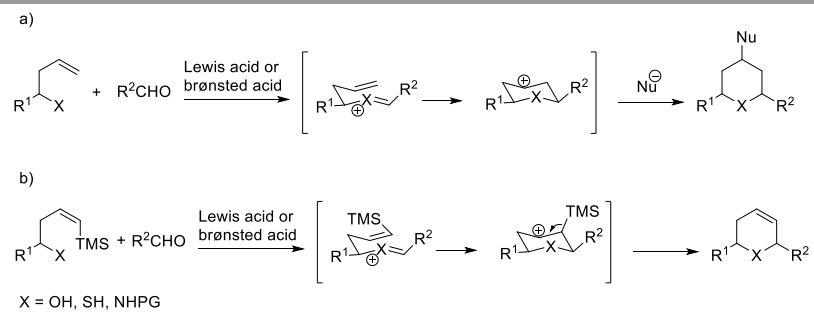

Scheme 1 a) Prins cyclization; b) silyl-Prins cyclization.

The aza-Prins cyclization has become an important tool for the synthesis of tetrahydropyridine cores, important intermediates in the synthesis of piperidine-type alkaloids. ${ }^{15}$ We started the study of this reaction under continuous flow conditions, 
between (Z)- $N$-(4-(trimethylsilyl)but-3-en-1-yl)aniline (1a) ${ }^{5 c}$ and 3-phenylpropanal (2a) in order to form the desired tetrahydropyridine 3a (Table 1). To our delight, the use of 1.5 equivalents of $\mathrm{FeCl}_{3}$ as Lewis acid and the same quantity of aldehyde 2a at room temperature with a flow rate of 200 $\mu \mathrm{L} \cdot \mathrm{min}^{-1}$ gave $33 \%$ of conversion rate (entry 1 ). By increasing the temperature to $50{ }^{\circ} \mathrm{C}$, an increment of the conversion was observed to $60 \%$, and it does not matter if the injection was made by one or two pumps (entries 2 and 3). Increasing the amount of the acid led to an insoluble reaction mixture. The use of boron trifluoride diethyl etherate $\left(\mathrm{BF}_{3} \cdot \mathrm{Et}_{2} \mathrm{O}\right)$ under the same conditions led to the product with a lower yield, but with improvement of the solubility, allowing us to test other conditions (entry 4). When the pressure was increased to 5 bar, a good increment in the conversion rate $(75 \%)$ was observed (entry 5), and the conversion was improved to $80 \%$ with two equivalents of acid and aldehyde (entry 6). Injecting the mixture of all the reactants with one pump gave a slightly better conversion rate $(90 \%$, entry 7$)$. The best result was observed when the solvent was changed for 1,4-dioxane and when the temperature was increased to $70{ }^{\circ} \mathrm{C}$, in which case a complete transformation was observed (entry 8).

Table 1 Optimization conditions for aza-silyl-Prins cyclization

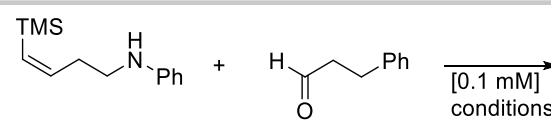

1a, 1 equiv

\begin{tabular}{cc}
\hline Entry & Equiv. o \\
\hline 1 & \\
2 & \\
3 & \\
4 & \\
$5^{[c]}$ & \\
$6^{[c]}$ & \\
$7^{[c]}$ & \\
$8^{[c]}$ & \\
\hline
\end{tabular}

2a, $X$ equiv conditions

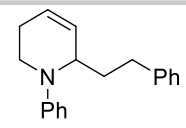

$3 a$

\begin{tabular}{ccc} 
Solvent & Injection mode $^{[b]}$ & Conversion rate to $3 \mathbf{a}(\%)^{[\mathrm{a}]}$ \\
\hline MeCN & One pump & 33 \\
MeCN & One pump & 60 \\
MeCN & Two pumps & 60 \\
MeCN & Two pumps & 40 \\
MeCN & Two pumps & 75 \\
MeCN & Two pumps & 80 \\
MeCN & One pump & 90 \\
1,4-Dioxane & One pump & 100
\end{tabular}

${ }^{a}$ Measured by ${ }^{1} \mathrm{H}$ NMR of the crude. ${ }^{b}$ One pump: all reagents in one pump, with a flow rate of $200 \mu \mathrm{L} \mathrm{min}{ }^{-1}$. Two pumps: mixture of amine and aldehyde in the first pump, Lewis acid in the second pump (flow rate of $100 \mu \mathrm{L} \mathrm{min}^{-1}$ for each pump). ${ }^{c}$ With a pressure of 5 bar.

With the optimized reaction conditions in hand, we investigated the scope of the method (Scheme 2). Different aldehydes (2a-d) were first tried in the presence of $(Z)-N$-(4-(trimethylsilyl)but3-en-1-yl)aniline (1a). When the reaction was performed with aldehydes bearing an aliphatic chain, the desired tetrahydropyridines $\mathbf{3} \mathbf{a}$ and $\mathbf{3 b}$ were isolated in very good yields (up to 90\%). The use of phenylacetaldehyde (2c) or 2 methylpentanal (2d) led to the products $\mathbf{3 c}$ and $\mathbf{3 d}$ respectively with lower yields, probably due to the steric hindrance. It is important to note that the reaction performed with $\mathbf{2 d}$ bearing a stereogenic center afforded tetrahydropyridine $\mathbf{3 d}$ as a $1: 1$ mixture of diastereomers. The reaction with an aromatic aldehyde or an enal did not work. Then, amine $\mathbf{1 b}$ bearing a non electronwithdrawing group, namely a benzyl group was studied, as we expected that the use of flow conditions could led to better yields than known in batch conditions. The tetrahydropyridines 3e-f were obtained with very low yields in the case of aliphatic aldehydes $\mathbf{2 a - b}$, and the reaction with the 2methylpentanal (2d) did not proceed.

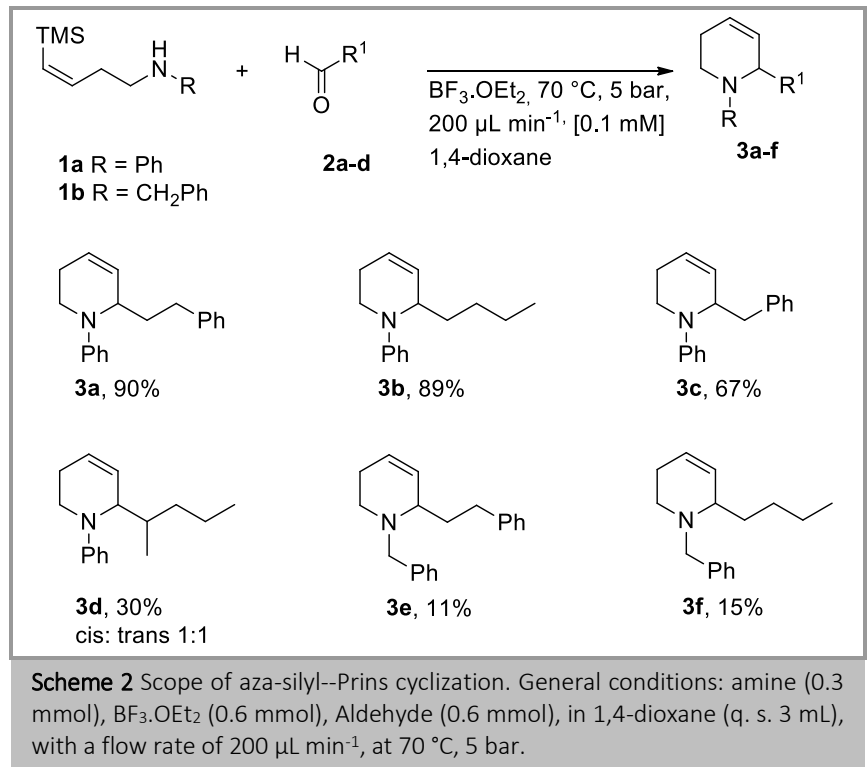

The reactivity of several pyridinecarboxaldehydes with $(Z)-N$ (4-(trimethylsilyl)but-3-en-1-yl)aniline (1a) was also tested under the same conditions, and resulted in unexpected products 4-6 (Scheme 3). On the one hand, the reaction with 4pyridinecarboxaldehyde $\mathbf{2 g}$ produced only the symmetrical triarylmethane (4) in a yield of $36 \%$, obtained by the double addition of the phenyl group of $\mathbf{1 a}$ to the aldehyde (Scheme 3a). Analogs of this product were reported by the reaction of pyridine carboxaldehydes and aniline derivatives, ${ }^{16}$ or by the reaction of aromatic aldehydes with different phenyl derivatives. ${ }^{17}$ 
On the other hand, the reaction of the silylated amine 1a with pyridine-2-carboxaldehyde derivatives gave polycyclic compounds as main products.

The reaction with pyridine-2-carboxaldehyde $\mathbf{2 h}$ gave the Prins derivative $\mathbf{3 h}$ in $14 \%$, and as main product the new tetracyclic derivative 5, which was isolated as its tetrafluoboride salt in $51 \%$ (Scheme 3b). Based on its NMR, we proposed that this compound presents a bridged diazepine, which is formed by the addition of the pyridinic nitrogen to the carbocation in an intramolecular cyclization. The confirmation of this interesting core was done by the use of 6-methoxy-pyridine-2carboxaldehyde $\mathbf{2} \mathbf{i}$, obtaining the tetrahydropyridine $\mathbf{3} \mathbf{i}$ in $18 \%$ and corresponding bridged diazepine 6 in $70 \%$ yield (Scheme 3c). The complete structure and relative stereochemistry of 6 were established by NMR as well as X-ray diffraction (Figure 1).

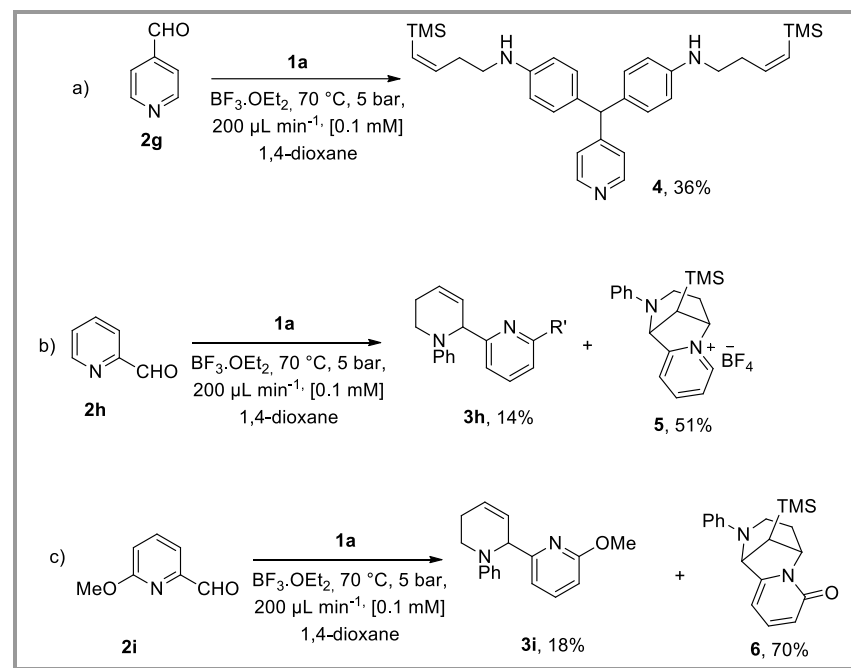

Scheme 3 Isolated products of the reaction of silylated amine 1 a with pyridine-carboxaldehyde derivatives

We propose a mechanism starting with the condensation of the amino group to the aldehyde, to obtain the corresponding iminium A (Scheme 4). Then, the diastereoselective attack of the $\pi$ electrons of the double bond to the iminium $\mathbf{A}$ could give the $\beta$-silylated cationic intermediate $\mathbf{B}$, in which structure, the silyl group is anti to the pyridine core. Then, the syn attack of the nitrogen of pyridine to the carbocation B could form a new carbon-nitrogen bond to give the five-membered heterocycle, pyridinium $\mathrm{C}$. When $\mathrm{R}=\mathrm{OMe}$, a final deprotection of the methoxy group leads to the corresponding pyridone $\mathbf{6}$. The stereochemistry proposed in the mechanism was in concordance with the X-ray diffraction of compound 6 (Figure 1).

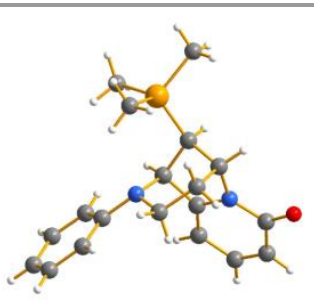

Figure 1 Ortep diagram of compound 6.

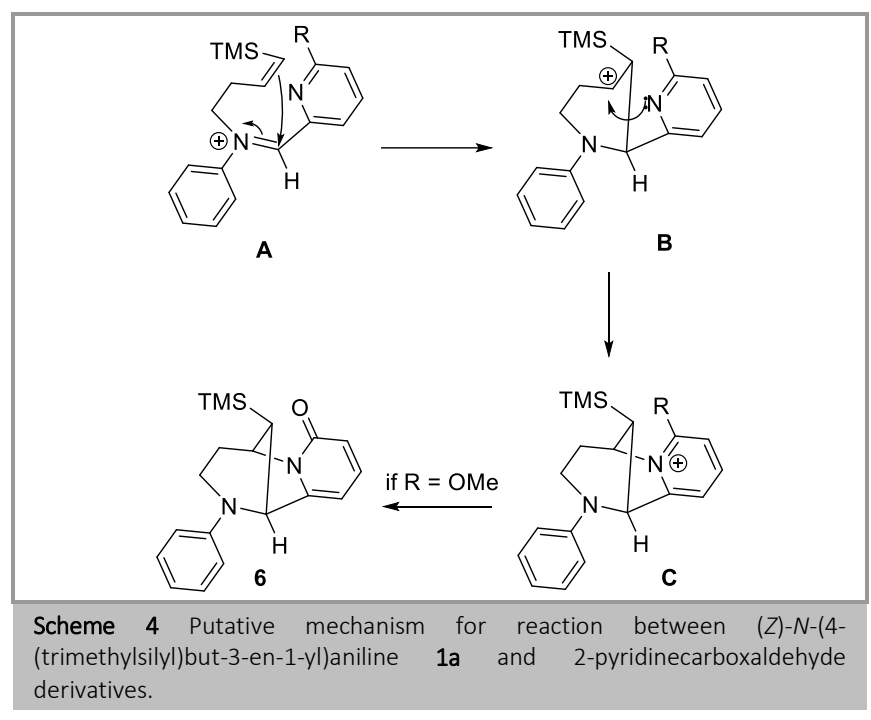

The oxa-Prins cyclization is known to give a mixture of dihydropyran or 4-substituted tetrahydropyran derivatives. Under batch conditions, the reaction between but-3-en-1-ol 7 and phenylacetaldehyde $\mathbf{2 c}$ in the presence of $\mathrm{BF}_{3} . \mathrm{OEt}_{2}$ in 1,4dioxane at reflux temperature $\left(115{ }^{\circ} \mathrm{C}\right)$, gave the mixture of dihydropyrans 8c and 9c as products in 70\% overall yield (Scheme 5), whose NMR data were consistent with the ones reported in the literature. ${ }^{2 \mathrm{~d}}$ The reaction under flow conditions was then studied, starting with similar conditions than the ones described above for the aza-Prins reaction (Scheme 2). A mixture of dihydropyrans 8c and 9c (19\%) together with a mixture of fluorinated products 10c and 11c (43\%, 1:4.5 syn:anti) were obtained (entry 1, Table 2). An unexpected selectivity for the anti isomer 11c over the syn 10c was observed. It is important to note that the syn isomer has been reported as the main product in the synthesis of 4fluorotetrahydropyrans by Prins cyclization under batch conditions. ${ }^{2 \mathrm{~b}, 6 \mathrm{a}, 6 \mathrm{~b}, 7 \mathrm{a}, 18}$ The reaction carried out at room temperature, gave the isomer 11c in better proportion, but the general yield was lower (entry 2). With DCM as solvent, and only the mixture of 4-fluorinated products $10 \mathrm{c}$ and $11 \mathrm{c}$ was obtained in 59\% yield, but the syn:anti ratio was inversed (2.3:1), in agreement with the results reported for the reaction under batch conditions ${ }^{2 \mathrm{~b}, 7 \mathrm{a}, 18 \mathrm{~b}}$ (entry 3). The reaction was then tested with a $1: 1$ mixture of dioxane-DCM as a solvent at $40{ }^{\circ} \mathrm{C}$, and the mixture of dihydropyranes $\mathbf{8 c}$ and $\mathbf{9 c}$ was obtained in low yield (10\%), and the yield of fluorinated products (58\%; 1:4 10c:11c) was increased (entry 4). Changes in solvent (DCE instead of DCM), equivalents of the acid (1 eq), residence time (flow decreased to $\left.150 \mu \mathrm{L} \cdot \mathrm{min}^{-1}\right)$ or acid $\left(\mathrm{HBF}_{4}\right)$, did not improve the result obtained (entries 5-8).

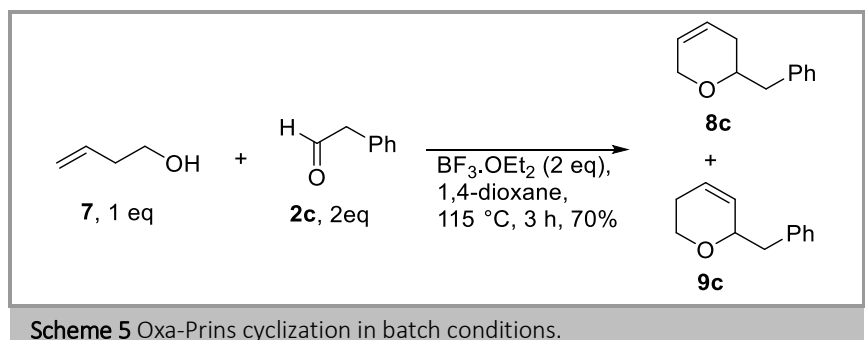


Table 2 Optimization conditions of oxa-Prins cyclization under flow conditions.

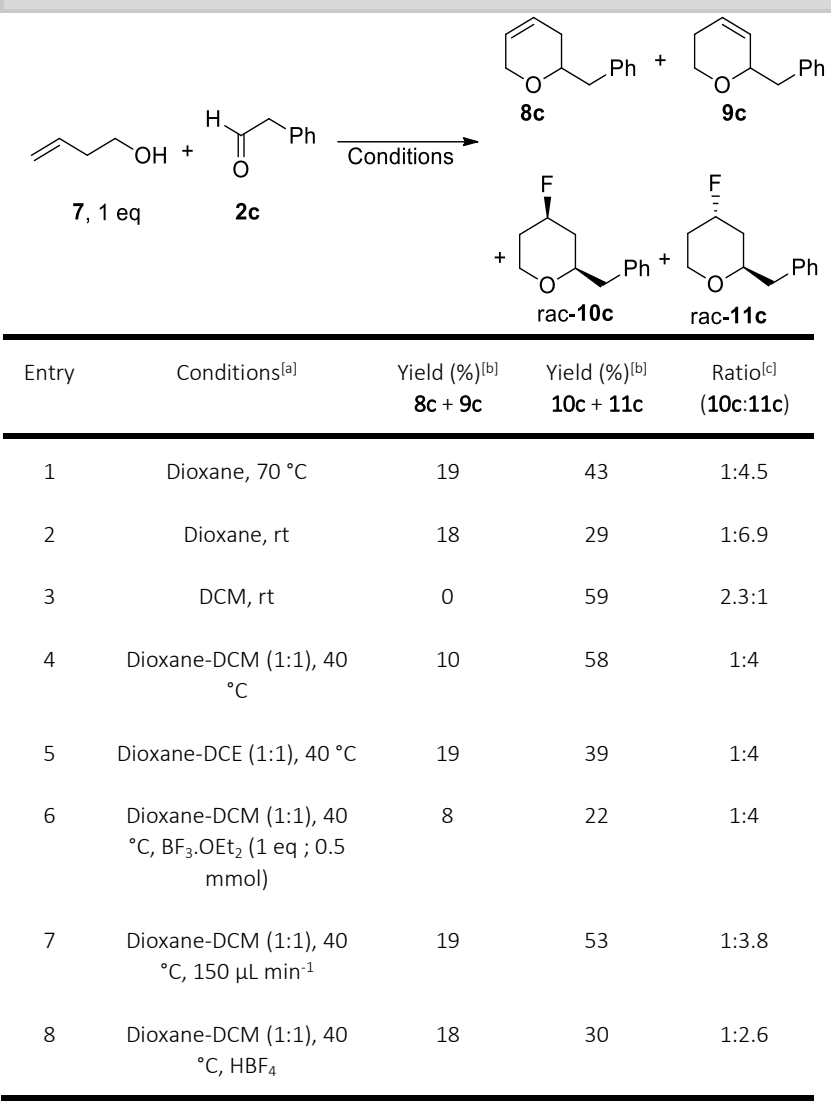

a General conditions: buten-1-ol (7) (0.5 mmol), BF $3 . \mathrm{OEt}_{2}$ (1 mmol) (except for entries 6 and 8), aldehyde $2 \mathrm{c}(1 \mathrm{mmol})$, in solvent (q. $5.5 \mathrm{~mL})$, all reagents in one pump, with a flow rate of $200 \mu \mathrm{L} \mathrm{min}{ }^{-1}$. b Isolated yields. [c] Measured by ${ }^{19} \mathrm{~F} \mathrm{NMR}$ in the crude reaction.

With the optimal conditions for this reaction being established, different aldehydes $\mathbf{2} \mathbf{j}$-p were studied (Table 3). In all cases, fluorinated compounds (10 and $\mathbf{1 1}$ ) were obtained as the major products, with a diastereomeric ratio in favor of the anti isomer 11. The reaction with an aliphatic aldehyde such as octanal $\mathbf{2 j}$ gave a good overall yield of $80 \%$; in favor to the fluorinated products $(50 \%)$ but with a lower syn:anti ratio $(1: 1.7 ; \mathbf{1 0 j}: \mathbf{1 1 j})$. In the case of a branched aldehyde $\mathbf{2} \mathbf{k}$, the overall yield and the ratio 10k:11k slightly decreased. The reaction with 4nitrobenzaldehyde $\mathbf{2 l}$ gave the mixture of 4-fluorinated products $\mathbf{1 0 l}$ and $\mathbf{1 1 1}$ in 42\%, with the best selectivity for the anti isomer $\mathbf{1 1 l}$ (syn:anti 1:6). Its stereochemistry was confirmed by X-ray diffraction analysis (Figure 2). The reaction with other aromatic aldehydes such as 2-nitrobenzaldehyde $\mathbf{2 m}$, 3-trifluromethylbenzaldehyde $\mathbf{2 n}$ and 4-chlorobenzaldehyde $\mathbf{2 0}$ gave poor yields. We can notice that with an electron donating group like in the 4 -acetamidobenzaldehyde $\mathbf{2 p}$, the reaction did not work.

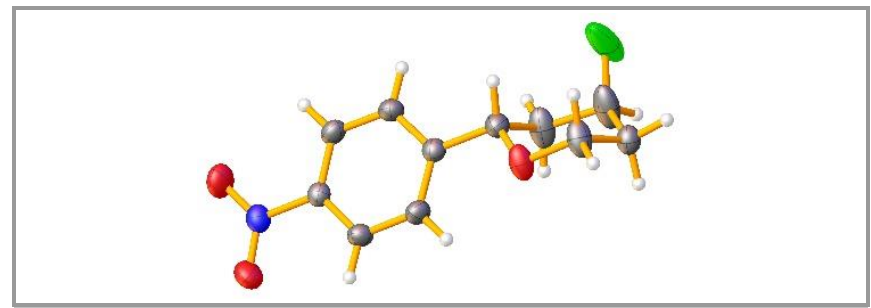

Figure 2 Ortep diagram of compound 11 .

\begin{tabular}{l} 
Table 3 Scope of the oxa-Prins cyclization \\
\hline 7,1 eq \\
Entry
\end{tabular}

General conditions: buten-1-ol (7) $(0.5 \mathrm{mmol}), \mathrm{BF}_{3} . \mathrm{OEt}_{2}$ (1 mmol), aldehyde (1 $\mathrm{mmol}$ ), in 1,4-dioxane-DCM (1:1) (q. s. $5 \mathrm{~mL}$ ), with a flow rate of $200 \mu \mathrm{L} \mathrm{min}^{-1}$, at 70 ${ }^{\circ} \mathrm{C}$ and 5 bar. ${ }^{\mathrm{a}}$ Isolated yields. ${ }^{\mathrm{b}}$ Reaction with a flow rate of $150 \mu \mathrm{L} \mathrm{min}{ }^{-1}$. [c] NMR data consistent with literature.

In conclusion, conditions for two Prins-type cyclizations were studied using flow chemistry. In the case of the aza-silyl-Prins reaction, the best results were observed with $\mathrm{N}$-phenyl protected amines in the presence of aliphatic, non-branched aldehydes. When using pyridinecarbaldehydes, unexpected products were obtained. On the other hand, the oxa-Prins reaction gave as main product the anti-4-fluorotetrahydropyran derivative, which is always reported as minor product under batch conditions.

General Methods: DCM was distilled over calcium hydride and stored with calcium chloride under Ar. Acetonitrile and 1,4-dioxane were used as purchased. ${ }^{1} \mathrm{H}$ NMR spectra were recorded in a Bruker AV-I $300 \mathrm{MHz}$ spectrometer at $298 \mathrm{~K}$, and were calibrated using residual $\mathrm{CHCl}_{3}(\delta=$ $7.26 \mathrm{ppm})$ or $\mathrm{MeOH}(\delta=4.87) \cdot{ }^{13} \mathrm{C}$ NMR spectra were recorded with a Bruker Avance 300 spectrometer at $75 \mathrm{MHz}$ and $298 \mathrm{~K}$, and were calibrated using $\mathrm{CDCl} 3(\delta=77.16 \mathrm{ppm})$ or $\mathrm{MeOH}(\delta=49.00) .{ }^{19} \mathrm{~F}$ NMR were recorded with a Bruker Avance 300 spectrometer at $282 \mathrm{MHz}$ and $\mathrm{CFCl}_{3}(\delta=0.00 \mathrm{ppm})$ was used as reference. ${ }^{1} \mathrm{H}$ NMR spectroscopic data 
are reported as follows: chemical shift $\delta$ [ppm] (multiplicity, coupling constant $[\mathrm{Hz}]$, integration). Multiplicities are reported as follows: $\mathrm{s}=$ singlet, $\mathrm{d}=$ doublet, $\mathrm{dd}=$ doublet of doublets, $\mathrm{t}=$ triplet, $\mathrm{dt}=$ doublet of triplets, $m=$ multiplet. High-resolution mass spectra (HRMS) were obtained with a Waters Xevo QTOF instrument with an electrospray ionisation source (ESI+), using enkephaline leucine as internal calibrant. Reagents were purchased from Sigma-Aldrich, Alfa Aesar, or Fluorochem and were used as received unless otherwise stated. (Z)-4trimethylsilyl-3-but- $N$-protected amines were synthesized as reported. ${ }^{5 c}$

\section{General procedure for Aza-Silyl Prins cyclization}

Stock solutions were prepared by adding $\mathrm{BF}_{3} . \mathrm{OEt}_{2}(0.68 \mathrm{mmol}, 2 \mathrm{eq})$ to a mixture of amine ( $0.34 \mathrm{mmol}, 1 \mathrm{eq})$ and aldehyde (0.68 mmol, $2 \mathrm{eq})$ in 1,4-dioxane, q.s. $3.4 \mathrm{~mL}$. Then $3 \mathrm{~mL}$ of solution was pumped through an easy Photochem E-series system from Vapourtec with a $10 \mathrm{~mL}$ reactor, at a flow rate of $200 \mu \mathrm{L} \mathrm{min}{ }^{-1}$ at $70{ }^{\circ} \mathrm{C}$, and 5 bar of pressure. After collecting the reaction, an aqueous solution of $\mathrm{NaOH} 1 \mathrm{M}$ was added, and the mixture was extracted with DCM $(10 \mathrm{~mL} \mathrm{X3).} \mathrm{The} \mathrm{combined} \mathrm{organic}$ layers were dried over $\mathrm{MgSO}_{4}$, filtered and evaporated under reduced pressure. The crude was purified by flash column chromatography.

\section{General procedure for Oxa-Prins cyclization in batch conditions}

$\mathrm{BF}_{3} . \mathrm{OEt}_{2}(0.6 \mathrm{mmol}, 2 \mathrm{eq})$ was added to a mixture of but-3-en-1-ol $(0.3$ mmol, 1 eq) and phenylacetaldehyde ( $0.6 \mathrm{mmol}, 2$ eq) in $3 \mathrm{~mL}$ of 1,4 dioxane, then the mixture was stirred at reflux temperature $\left(115^{\circ} \mathrm{C}\right)$ for $3 \mathrm{~h}$. Then, water was added and the reaction was extracted with DCM (10 $\mathrm{mL} \mathrm{X} \mathrm{3);} \mathrm{the} \mathrm{combined} \mathrm{organic} \mathrm{layers} \mathrm{were} \mathrm{dried} \mathrm{over} \mathrm{MgSO}_{4}$, filtered and evaporated under reduced pressure. The crude was purified by flash column chromatography.

\section{General Procedure for Oxa-Prins cyclization}

Stock solutions were prepared by adding $\mathrm{BF}_{3} . \mathrm{OEt}_{2}(1.0 \mathrm{mmol}, 2 \mathrm{eq})$ to a mixture of the alcohol $(0.5 \mathrm{mmol}, 1 \mathrm{eq})$ the aldehyde $(1.0 \mathrm{mmol}, 2 \mathrm{eq})$ in 1,4-dioxane-DCM (1:1), q.s. $5.4 \mathrm{~mL}$. Then $5 \mathrm{~mL}$ of each solution was pumped through an easy Photochem E-series system from Vapourtec with a $10 \mathrm{~mL}$ reactor, at a flow rate of $200 \mu \mathrm{L} \mathrm{min}-1$ or $150 \mu \mathrm{L} \mathrm{min}{ }^{-1}$ at 40 ${ }^{\circ} \mathrm{C}$, and 5 bar of pressure. After collecting the reaction, water was added, and the mixture was extracted with DCM (10 mL X3). The combined organic layers were dried over $\mathrm{MgSO}_{4}$, filtered and evaporated under reduced pressure. The crude was purified by flash column chromatography.

\section{6-phenethyl-1-phenyl-1,2,3,6-tetrahydropyridine (3a)}

Prepared by the general procedure for Aza-Silyl Prins cyclization. Isolated by flash column chromatography with a mixture of pentaneDCM (9:1) as yellow pale oil, (71 mg, 90\%).

IR ATR: = 3052, 3024, 2956, 2924, 2858, 1598, 1502, 1318, 1245, 745, $688 \mathrm{~cm}^{-1}$.

$\left.{ }^{1} \mathrm{H} \mathrm{NMR} \mathrm{(300} \mathrm{MHz,} \mathrm{CDCl}_{3}\right) \delta=7.29-7.15(\mathrm{~m}, 7 \mathrm{H}), 6.82(\mathrm{~d}, J=8.1 \mathrm{~Hz}, 2 \mathrm{H})$ $6.74(\mathrm{t}, J=7.2 \mathrm{~Hz}, 1 \mathrm{H}), 5.88(\mathrm{~s}, 2 \mathrm{H}), 4.1(\mathrm{t}, J=6.8 \mathrm{~Hz}, 1 \mathrm{H}), 3.64(\mathrm{dd}, J=$ $13.4,4.9 \mathrm{~Hz}, 1 \mathrm{H}), 3.33-3.18(\mathrm{~m}, 1 \mathrm{H}), 2.79-2.64(\mathrm{~m}, 2 \mathrm{H}), 2.39-2.28(\mathrm{~m}$, 1H), 2.01 (brd, $J=16.9 \mathrm{~Hz}, 1 \mathrm{H}), 1.92$ (q, $J=7.4 \mathrm{~Hz}, 2 \mathrm{H}$ ).

${ }^{13} \mathrm{C}$ NMR (75 MHz, $\left.\mathrm{CDCl}_{3}\right) \delta=150.3\left(\mathrm{C}_{\mathrm{q}}\right), 142.3\left(\mathrm{C}_{\mathrm{q}}\right), 129.6(\mathrm{CH}), 129.3$ $(\mathrm{CH}), 128.5(\mathrm{CH}), 128.4(\mathrm{CH}), 126.0(\mathrm{CH}), 125.9(\mathrm{CH}), 118.0(\mathrm{CH}), 115.6$ (CH), $56.6(\mathrm{CH}), 41.0\left(\mathrm{CH}_{2}\right), 34.7\left(\mathrm{CH}_{2}\right), 32.7\left(\mathrm{CH}_{2}\right), 24.3\left(\mathrm{CH}_{2}\right)$.

HRMS TOF ES ${ }^{+}$calcd. for $\mathrm{C}_{19} \mathrm{H}_{22} \mathrm{~N}[\mathrm{M}+\mathrm{H}]^{+}$264.1752; found 264.1744 .

\section{6-butyl-1-phenyl-1,2,3,6-tetrahydropyridine (3b)}

Prepared by the general procedure for Aza-Silyl Prins cyclization. Isolated by flash column chromatography with a mixture of pentaneDCM (9:1) as colorless oil, (58 mg, 89\%).

IR ATR $=3059,3025,2955,2926,2857,1596,1500,1386,1240,1033$, $745,689 \mathrm{~cm}^{-1}$.

${ }^{1} \mathrm{H} \mathrm{NMR}\left(300 \mathrm{MHz}, \mathrm{CDCl}_{3}\right) \delta=7.26(\mathrm{dd}, J=8.8,7.2 \mathrm{~Hz}, 2 \mathrm{H}), 6.90(\mathrm{~d}, J=$ $8.2 \mathrm{~Hz}, 2 \mathrm{H}), 6.76(\mathrm{t}, J=7.2 \mathrm{~Hz}, 1 \mathrm{H}), 5.87(\mathrm{~s}, 2 \mathrm{H}), 4.06(\mathrm{~m}, 1 \mathrm{H}), 3.66(\mathrm{dd}, J=$ 13.4, $3.7 \mathrm{~Hz}, 1 \mathrm{H}$ ), 3.25 (ddd, $J=13.2,10.9,4.0 \mathrm{~Hz}, 1 \mathrm{H}$ ), 2.44-2.28 (m, 1H), $2.02(\mathrm{~d}, J=17.9 \mathrm{~Hz}, 1 \mathrm{H}), 1.67-1.57(\mathrm{~m}, 2 \mathrm{H}), 1.48-1.31(\mathrm{~m}, 4 \mathrm{H}), 0.93(\mathrm{t}, J=$ $7.0 \mathrm{~Hz}, 3 \mathrm{H})$
${ }^{13} \mathrm{C}$ NMR (75 MHz, $\left.\mathrm{CDCl}_{3}\right) \delta 150.3\left(\mathrm{C}_{\mathrm{q}}\right), 130.0(\mathrm{CH}), 129.3(\mathrm{CH}), 125.5$ (CH), $117.5(\mathrm{CH}), 115.1(\mathrm{CH}), 56.2(\mathrm{CH}), 40.5\left(\mathrm{CH}_{2}\right), 32.7\left(\mathrm{CH}_{2}\right), 28.7$ $\left(\mathrm{CH}_{2}\right), 24.3\left(\mathrm{CH}_{2}\right), 23.0\left(\mathrm{CH}_{2}\right), 14.2\left(\mathrm{CH}_{3}\right)$.

HRMS TOF ES ${ }^{+}$calcd. for $\mathrm{C}_{15} \mathrm{H}_{22} \mathrm{~N}[\mathrm{M}+\mathrm{H}]^{+}$216.1752; found 216.1742 .

\section{6-(pentan-2-yl)-1-phenyl-1,2,3,6-tetrahydropyridine (3d)}

Prepared by the general procedure for Aza-Silyl Prins cyclization. Isolated by flash column chromatography with a mixture of pentaneDCM (20:1) as (mixture of isomers a and b): colorless oil, (21 mg, 30\%).

IR ATR = 3060, 2956, 2926, 2870, 1596, 1499, 1378, 1235, 984, 745, 689 $\mathrm{cm}^{-1}$.

${ }^{1} \mathrm{H}$ NMR (300 MHz, $\left.\mathrm{CDCl}_{3}\right) \delta=7.25-7.19(\mathrm{~m}, 4 \mathrm{H}), 6.87(\mathrm{~d}, J=8.1 \mathrm{~Hz}, 4 \mathrm{H})$, 6.74-6.70 (m, 2H), 5.93-5.83 (m, 4H), 3.87 (brs, $1 \mathrm{H}, \mathrm{Ha}), 3.79(\mathrm{~d}, J=7.0$ $\mathrm{Hz}, 1 \mathrm{H}, \mathrm{Hb}), 3.70-3.62(\mathrm{~m}, 2 \mathrm{H}), 3.39-3.28(\mathrm{~m}, 2 \mathrm{H}), 2.38-2.27(\mathrm{~m}, 2 \mathrm{H})$, 2.01-1.92 (m, 4H), 1.61-1.40 (m, 4H), 1.33-1.10 (m, 4H), $1.00(\mathrm{~d}, J=6.8$ $\mathrm{Hz}, 3 \mathrm{Ha}), 0.92-0.87$ (m, 9H).

${ }^{13} \mathrm{C}$ NMR $\left(75 \mathrm{MHz}, \mathrm{CDCl}_{3}\right) \delta=150.8\left(\mathrm{C}_{\mathrm{q}}\right), 150.5\left(\mathrm{C}_{\mathrm{q}}\right), 129.2(\mathrm{CH}), 128.4$ $(\mathrm{CH}), 127.8(\mathrm{CH}), 126.6(\mathrm{CH}), 126.4(\mathrm{CH}), 125.7(\mathrm{CH}), 117.4(\mathrm{CH}), 117.3$ $(\mathrm{CH}), 115.2(\mathrm{CH}), 115.1(\mathrm{CH}), 61.4(\mathrm{CH}), 60.6(\mathrm{CH}), 42.0\left(\mathrm{CH}_{2}\right), 41.8$ $\left(\mathrm{CH}_{2}\right), 37.1(\mathrm{CH}), 36.6\left(\mathrm{CH}_{2}\right), 36.5(\mathrm{CH}), 35.3\left(\mathrm{CH}_{2}\right), 23.8\left(\mathrm{CH}_{2}\right), 23.4$ $\left(\mathrm{CH}_{2}\right), 20.7\left(\mathrm{CH}_{2}\right), 20.5\left(\mathrm{CH}_{2}\right), 17.1\left(\mathrm{CH}_{3}\right), 16.1\left(\mathrm{CH}_{3}\right), 14.6\left(\mathrm{CH}_{3}\right), 14.5$ $\left(\mathrm{CH}_{3}\right)$.

HRMS TOF ES ${ }^{+}$calcd. for $\mathrm{C}_{16} \mathrm{H}_{24} \mathrm{~N}[\mathrm{M}+\mathrm{H}]^{+} 230.1909$; found 230.1909

\section{1-benzyl-6-phenethyl-1,2,3,6-tetrahydropyridine (3e)}

Prepared by the general procedure for Aza-Silyl Prins cyclization. Isolated by flash column chromatography with a mixture of pentanediethylether-triethylamine (100:2:1) as yellow oil, ( $9 \mathrm{mg}, 11 \%)$.

IR ATR $=3084,3060,3024,2930,2796,1602,1494,1452,1361,1104$, $1072,727,695 \mathrm{~cm}^{-1}$.

$\left.{ }^{1} \mathrm{H} \mathrm{NMR} \mathrm{(300} \mathrm{MHz,} \mathrm{CDCl}_{3}\right) \delta=7.38-7.08(\mathrm{~m}, 10 \mathrm{H}), 5.82-5.76(\mathrm{~m}, 1 \mathrm{H}), 5.59$ (dd, $J=10.1,2.4 \mathrm{~Hz}, 1 \mathrm{H}$ ), 3.88 (d, $J=13.6 \mathrm{~Hz}, 1 \mathrm{H}), 3.38$ (d, $J=13.6 \mathrm{~Hz}$, 1H), 2.96 (brs, 1H), 2.86 (dt, J = 11.7, $5.6 \mathrm{~Hz}, 1 \mathrm{H}), 2.77-2.54(\mathrm{~m}, 2 \mathrm{H}), 2.37$ (dt, $J=11.7,5.6 \mathrm{~Hz}, 1 \mathrm{H}), 1.99(\mathrm{brs}, 2 \mathrm{H}), 1.97-1.72(\mathrm{~m}, 2 \mathrm{H})$

${ }^{13} \mathrm{C}$ NMR $\left(75 \mathrm{MHz}, \mathrm{CDCl}_{3}\right) \delta=143.1\left(\mathrm{C}_{\mathrm{q}}\right), 139.8\left(\mathrm{C}_{\mathrm{q}}\right), 129.8(\mathrm{CH}), 1289.0$ $(\mathrm{CH}), 128.5(\mathrm{CH}), 128.4(\mathrm{CH}), 128.3(\mathrm{CH}), 126.9(\mathrm{CH}), 125.8(\mathrm{CH}), 125.7$ $(\mathrm{CH}), 58.6(\mathrm{CH}), 58.2\left(\mathrm{CH}_{2}\right), 46.1\left(\mathrm{CH}_{2}\right), 35.3\left(\mathrm{CH}_{2}\right), 31.6\left(\mathrm{CH}_{2}\right), 23.9$ $\left(\mathrm{CH}_{2}\right)$.

HRMS TOF ES ${ }^{+}$calcd. for $\mathrm{C}_{20} \mathrm{H}_{24} \mathrm{~N}[\mathrm{M}+\mathrm{H}]^{+}$278.1909; found 278.1906.

\section{1-benzyl-6-butyl-1,2,3,6-tetrahydropyridine (3f)}

Prepared by the general procedure for Aza-Silyl Prins cyclization. Isolated by flash column chromatography with a mixture of pentanediethylether-triethylamine (100:2:1) as yellow oil, (10 mg, 15\%).

IR ATR $=3062,3026,2954,2929,2860,1731,1629,1453,1429,1360$, $1072,1028,727,696 \mathrm{~cm}^{-1}$.

${ }^{1} \mathrm{H}$ NMR (300 MHz, $\left.\mathrm{CDCl}_{3}\right) \delta=7.42-7.20(\mathrm{~m}, 5 \mathrm{H}), 5.84-5.74(\mathrm{~m}, 1 \mathrm{H}), 5.66$ (dd, $J=10.1,2.4 \mathrm{~Hz}, 1 \mathrm{H}), 3.94(\mathrm{~d}, J=13.6 \mathrm{~Hz}, 1 \mathrm{H}), 3.40(\mathrm{~d}, J=13.6 \mathrm{~Hz}$, $1 \mathrm{H}), 2.94-2.85(\mathrm{~m}, 2 \mathrm{H}), 2.39$ (dt, $J=12.0,6.0 \mathrm{~Hz}, 1 \mathrm{H}), 2.02$ (brs, 2H), 1.66 $1.55(\mathrm{~m}, 2 \mathrm{H}), 1.52-1.19(\mathrm{~m}, 4 \mathrm{H}), 0.90(\mathrm{t}, J=7.0 \mathrm{~Hz}, 3 \mathrm{H})$.

${ }^{13} \mathrm{C}$ NMR (75 MHz, $\left.\mathrm{CDCl}_{3}\right) \delta=139.7\left(\mathrm{C}_{\mathrm{q}}\right), 130.2(\mathrm{CH}), 128.9(\mathrm{CH}), 128.2$ $(\mathrm{CH}), 126.8(\mathrm{CH}), 125.1(\mathrm{CH}), 59.0(\mathrm{CH}), 58.1\left(\mathrm{CH}_{2}\right), 46.2\left(\mathrm{CH}_{2}\right), 33.1$ $\left(\mathrm{CH}_{2}\right), 27.6\left(\mathrm{CH}_{2}\right), 24.0\left(\mathrm{CH}_{2}\right), 23.0\left(\mathrm{CH}_{2}\right), 14.2\left(\mathrm{CH}_{3}\right)$.

HRMS TOF ES+ calcd. for $\mathrm{C}_{16} \mathrm{H}_{24} \mathrm{~N}[\mathrm{M}+\mathrm{H}]^{+} 230.1909$; found 230.1901 .

\section{4,4'-(pyridin-4-ylmethylene)bis(N-((Z)-4-(trimethylsilyl)but-3-en-} 1-yl)aniline) (4)

Prepared by the general procedure for Aza-Silyl Prins cyclization. Isolated by flash column chromatography with a mixture of DCM-MeOH (20:1) as yellow oil, (29 $\mathrm{mg}, 36 \%$ ).

IR ATR = 3020, 2952, 2895, 2851, 1610, 1515, 1411, 1321, 1246, 1178, $833,761 \mathrm{~cm}^{-1}$.

${ }^{1} \mathrm{H}$ NMR (300 MHz, MeOD) $\delta=8.35(\mathrm{~d}, J=5.5 \mathrm{~Hz}, 2 \mathrm{H}), 7.13(\mathrm{~d}, J=5.5 \mathrm{~Hz}$, $2 \mathrm{H}), 6.84(\mathrm{~d}, J=8.6 \mathrm{~Hz}, 4 \mathrm{H}), 6.57(\mathrm{~d}, J=8.6 \mathrm{~Hz}, 4 \mathrm{H}), 6.35(\mathrm{dt}, J=14.1,7.2$ 
$\mathrm{Hz}, 2 \mathrm{H}), 5.59(\mathrm{dt}, J=14.1,1.3 \mathrm{~Hz}, 2 \mathrm{H}), 5.30(\mathrm{~s}, 1 \mathrm{H}), 3.12(\mathrm{t}, J=7.2 \mathrm{~Hz}, 4 \mathrm{H})$ $2.42(\mathrm{q}, J=7.2 \mathrm{~Hz}, 4 \mathrm{H}), 0.09(\mathrm{~s}, 18 \mathrm{H})$

${ }^{13} \mathrm{C}$ NMR (75 MHz, MeOD) $\delta=157.8\left(\mathrm{C}_{\mathrm{q}}\right), 149.6(\mathrm{CH}), 148.3\left(\mathrm{C}_{\mathrm{q}}\right), 147.0$ $(\mathrm{CH}), 132.5\left(\mathrm{C}_{\mathrm{q}}\right), 132.0(\mathrm{CH}), 131.0(\mathrm{CH}), 126.3(\mathrm{CH}), 114.2(\mathrm{CH}), 56.0$ $(\mathrm{CH}), 44.7\left(\mathrm{CH}_{2}\right), 34.3\left(\mathrm{CH}_{2}\right), 0.3\left(\mathrm{CH}_{3}\right)$.

HRMS TOF ES ${ }^{+}$calcd. for $\mathrm{C}_{32} \mathrm{H}_{46} \mathrm{~N}_{3} \mathrm{Si}_{2}[\mathrm{M}+\mathrm{H}]^{+} 528.3230$; found 528.3225 .

\section{1-phenyl-1,2,5,6-tetrahydro-2,2'-bipyridine (3h)}

Prepared by the general procedure for Aza-Silyl Prins cyclization, using a mixture 1,4-dioxane-MeCN (9:1) as solvent. Isolated by flash column chromatography with DCM as yellow oil, (10 mg, 14\%).

IR: $\tilde{v}=3037,3005,2916,2833,1596,1587,1501,1465,1432,848,745$, $689 \mathrm{~cm}^{-1}$.

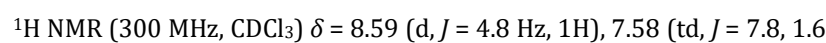
$\mathrm{Hz}, 1 \mathrm{H}), 7.30(\mathrm{~d}, J=7.9 \mathrm{~Hz}, 1 \mathrm{H}), 7.23-7.07(\mathrm{~m}, 3 \mathrm{H}), 6.85(\mathrm{~d}, J=8.1 \mathrm{~Hz}, 2 \mathrm{H})$, $6.72(\mathrm{t}, J=7.2 \mathrm{~Hz}, 1 \mathrm{H}), 6.16-6.05(\mathrm{~m}, 1 \mathrm{H}), 6.04-5.96(\mathrm{~m}, 1 \mathrm{H}), 5.23(\mathrm{~s}, 1 \mathrm{H})$, $3.73(\mathrm{dt}, J=12.8,4.8 \mathrm{~Hz}, 1 \mathrm{H}), 3.56$ (ddd, $J=12.8,8.4,4.4 \mathrm{~Hz}, 1 \mathrm{H}), 2.48$ $2.35(\mathrm{~m}, 1 \mathrm{H}), 2.34-2.18(\mathrm{~m}, 1 \mathrm{H})$.

${ }^{13} \mathrm{C} \mathrm{NMR}\left(75 \mathrm{MHz}, \mathrm{CDCl}_{3}\right) \delta=162.2\left(\mathrm{C}_{\mathrm{q}}\right), 149.8\left(\mathrm{C}_{\mathrm{q}}\right), 149.4(\mathrm{CH}), 137.2$ (CH), $129.2(\mathrm{CH}), 128.8(\mathrm{CH}), 125.9(\mathrm{CH}), 121.9(\mathrm{CH}), 120.9(\mathrm{CH}), 118.2$ $(\mathrm{CH}), 115.2(\mathrm{CH}), 62.0\left(\mathrm{CH}_{2}\right), 43.1(\mathrm{CH}), 24.8(\mathrm{CH})$.

HRMS TOF ES+ calcd. for $\mathrm{C}_{16} \mathrm{H}_{17} \mathrm{~N}_{2}[\mathrm{M}+\mathrm{H}]^{+}$237.1392; found 237.1388.

2-phenyl-11-(trimethylsilyl)-2,3,4,5-tetrahydro-1H-1,5methanopyrido[1,2-a][1,4]diazepin-6-ium tetrafluoroborate (5)

Prepared by the general procedure for Aza-Silyl Prins cyclization, using a mixture 1,4-dioxane-MeCN (9:1) as solvent. Isolated by flash column chromatography with a mixture of DCM-MeOH (9:1) as brown oil, (48 $\mathrm{mg}, 51 \%)$.

IR ATR = 3051, 2952, 2853, 1710, 1624, 1596, 1579, 1492, 1475, 1250 1056, 1030, 894, 837, 756, 726, $693 \mathrm{~cm}^{-1}$.

${ }^{1} \mathrm{H} \mathrm{NMR}\left(300 \mathrm{MHz}, \mathrm{CDCl}_{3}\right) \delta=9.11(\mathrm{~d}, J=5.9 \mathrm{~Hz}, 1 \mathrm{H}), 8.27(\mathrm{t}, J=7.8 \mathrm{~Hz}$, $1 \mathrm{H}), 7.89(\mathrm{t}, J=6.8 \mathrm{~Hz}, 1 \mathrm{H}), 7.49(\mathrm{~d}, J=7.8 \mathrm{~Hz}, 1 \mathrm{H}), 7.30(\mathrm{t}, J=8.0 \mathrm{~Hz}, 2 \mathrm{H})$, $6.94(\mathrm{t}, J=7.4 \mathrm{~Hz}, 1 \mathrm{H}), 6.86(\mathrm{~d}, J=8.1 \mathrm{~Hz}, 2 \mathrm{H}), 5.69(\mathrm{brs}, 1 \mathrm{H}), 5.55(\mathrm{~d}, J=$ $3.7 \mathrm{~Hz}, 1 \mathrm{H}$ ), 3.32 (dd, $J=12.4,6.0 \mathrm{~Hz}, 1 \mathrm{H}), 2.47-2.32(\mathrm{~m}, 2 \mathrm{H}), 2.24$ (brs, $1 \mathrm{H}), 2.20-2.10(\mathrm{~m}, 1 \mathrm{H}), 0.29(\mathrm{~s}, 9 \mathrm{H})$.

${ }^{13} \mathrm{C} \mathrm{NMR}\left(75 \mathrm{MHz}, \mathrm{CDCl}_{3}\right) \delta=154.6\left(\mathrm{C}_{\mathrm{q}}\right), 148.1\left(\mathrm{C}_{\mathrm{q}}\right), 146.0(\mathrm{CH}), 141.1$ $(\mathrm{CH}), 129.8(\mathrm{CH}), 127.1(\mathrm{CH}), 122.1(\mathrm{CH}), 121.4(\mathrm{CH}), 116.7(\mathrm{CH}), 72.2$ $(\mathrm{CH}), 64.7(\mathrm{CH}), 41.2\left(\mathrm{CH}_{2}\right), 40.7(\mathrm{CH}), 27.4\left(\mathrm{CH}_{2}\right),-1.1\left(\mathrm{CH}_{3}\right) .{ }^{19} \mathrm{~F}$ NMR $\left(282 \mathrm{MHz}, \mathrm{CDCl}_{3}\right) \delta=-152.0(\mathrm{~s}),-152.1(\mathrm{~s})$.

HRMS TOF ES ${ }^{+}$calcd. for $\mathrm{C}_{19} \mathrm{H}_{25} \mathrm{~N}_{2} \mathrm{Si}[\mathrm{M}]^{+} 309.1787$; found 309.1782 .

\section{6'-methoxy-1-phenyl-1,2,5,6-tetrahydro-2,2'-bipyridine (3i)}

Prepared by the general procedure for Aza-Silyl Prins cyclization. Isolated by flash column chromatography with DCM as yellow oil, (14 mg, $18 \%$ yield).

IR ATR = 3036, 2947, 2916, 2851, 1594, 1575, 1502, 1463, 1428, 1412, $1308,1256,1030,987,823,785,746,689 \mathrm{~cm}^{-1}$.

${ }^{1} \mathrm{H}$ NMR (300 MHz, $\left.\mathrm{CDCl}_{3}\right) \delta=7.46(\mathrm{t}, J=7.8 \mathrm{~Hz}, 1 \mathrm{H}), 7.19(\mathrm{t}, J=8.0 \mathrm{~Hz}$, $2 \mathrm{H}), 6.89-6.83(\mathrm{~m}, 3 \mathrm{H}), 6.71(\mathrm{t}, J=7.3 \mathrm{~Hz}, 1 \mathrm{H}), 6.56(\mathrm{~d}, J=8.0 \mathrm{~Hz}, 1 \mathrm{H})$, 6.15 (brd, $J=10.0 \mathrm{~Hz}, 1 \mathrm{H}), 6.07-5.94(\mathrm{~m}, 1 \mathrm{H}), 5.15(\mathrm{~s}, 1 \mathrm{H}), 3.93(\mathrm{~s}, 3 \mathrm{H})$, $3.79(\mathrm{dt}, J=13.1,4.4 \mathrm{~Hz}, 1 \mathrm{H}), 3.59-3.50(\mathrm{~m}, 1 \mathrm{H}), 2.54-2.35(\mathrm{~m}, 1 \mathrm{H}), 2.24$ $(\mathrm{m}, 1 \mathrm{H})$.

${ }^{13} \mathrm{C}$ NMR (75 MHz, $\left.\mathrm{CDCl}_{3}\right) \delta 164.0\left(\mathrm{C}_{\mathrm{q}}\right), 159.3\left(\mathrm{C}_{\mathrm{q}}\right), 149.8\left(\mathrm{C}_{\mathrm{q}}\right), 139.2(\mathrm{CH})$, $129.2(\mathrm{CH}), 128.9(\mathrm{CH}), 125.8(\mathrm{CH}), 117.5(\mathrm{CH}), 114.5(\mathrm{CH}), 113.2(\mathrm{CH})$, 108.6 (CH), $61.5(\mathrm{CH}), 53.5\left(\mathrm{CH}_{3}\right), 41.9\left(\mathrm{CH}_{2}\right), 24.8\left(\mathrm{CH}_{2}\right)$.

HRMS TOF ES ${ }^{+}$calcd. for $\mathrm{C}_{17} \mathrm{H}_{19} \mathrm{~N}_{2} \mathrm{O}[\mathrm{M}+\mathrm{H}]^{+} 267.1497$; found 267.1484.

2-phenyl-11-(trimethylsilyl)-2,3,4,5-tetrahydro-1,5methanopyrido[1,2-a][1,4]diazepin-7(1H)-one (6)

Prepared by the general procedure for Aza-Silyl Prins cyclization. Isolated by flash column chromatography with a mixture of DCM-MeOH (19:1) as white crystals, $\mathrm{mp}=162-165^{\circ} \mathrm{C},(68 \mathrm{mg}, 70 \%)$.

IR ATR = 3061, 3038, 3001, 2951, 2859, 2839, 1650, 1581, 1539, 1504, $1494,1468,1242,1210,1183,979,878,833,794,753,737 \mathrm{~cm}^{-1}$.
${ }^{1} \mathrm{H}$ NMR (300 MHz, $\left.\mathrm{CDCl}_{3}\right) \delta=7.29(\mathrm{t}, 8.0 \mathrm{~Hz}, 2 \mathrm{H}), 7.20(\mathrm{dd}, J=9.1,6.6 \mathrm{~Hz}$, $1 \mathrm{H}), 6.95-6.81(\mathrm{~m}, 3 \mathrm{H}), 6.43(\mathrm{~d}, J=9.1, \mathrm{~Hz}, 1 \mathrm{H}), 5.86(\mathrm{~d}, J=6.6 \mathrm{~Hz}, 1 \mathrm{H})$, $5.21(\mathrm{t}, J=4.4 \mathrm{~Hz}, 1 \mathrm{H}), 5.09$ (d, $J=3.8 \mathrm{~Hz}, 1 \mathrm{H}), 3.25(\mathrm{dd}, J=12.1,6.4 \mathrm{~Hz}$, $1 \mathrm{H}), 2.55(\mathrm{td}, J=11.5,5.9 \mathrm{~Hz}, 1 \mathrm{H}), 2.29-2.06(\mathrm{~m}, 2 \mathrm{H}), 1.65$ (brs, $1 \mathrm{H}), 0.24$ (s, 9H).

${ }^{13} \mathrm{C}$ NMR (75 MHz, $\left.\mathrm{CDCl}_{3}\right) \delta=160.8\left(\mathrm{C}_{\mathrm{q}}\right), 149.3\left(\mathrm{C}_{\mathrm{q}}\right), 148.4\left(\mathrm{C}_{\mathrm{q}}\right), 139.8$ $(\mathrm{CH}), 129.3(\mathrm{CH}), 120.1(\mathrm{CH}), 119.4(\mathrm{CH}), 116.6(\mathrm{CH}), 99.9(\mathrm{CH}), 64.6$ $(\mathrm{CH}), 58.5(\mathrm{CH}), 41.6\left(\mathrm{CH}_{2}\right), 39.9(\mathrm{CH}), 25.7\left(\mathrm{CH}_{2}\right),-0.9\left(\mathrm{CH}_{3}\right)$.

HRMS TOF ES ${ }^{+}$calcd. for $\mathrm{C}_{19} \mathrm{H}_{25} \mathrm{~N}_{2} \mathrm{OSi}[\mathrm{M}+\mathrm{H}]^{+}$325.1736; found 325.1742 .

\section{Cis-2-benzyl-4-fluorotetrahydro-2H-pyran (10c)}

Prepared according to the general procedure for Oxa-Prins cyclization. Purified by flash column chromatography with a mixture of pentanediethylether (30:1) as colorless oil, (11 mg, 11\%).

IR ATR = 3062, 3028, 2954, 2925, 2849, 1495, 1454, 1369, 1157, 1116, $1081,1031,996,983,750,697 \mathrm{~cm}^{-1}$.

${ }^{1} \mathrm{H}$ NMR $\left(300 \mathrm{MHz}, \mathrm{CDCl}_{3}\right) \delta=7.40-7.20(\mathrm{~m}, 5 \mathrm{H}), 4.65(\mathrm{dtt}, J=49.2,10.8$, $5.0 \mathrm{~Hz}, 1 \mathrm{H}), 4.09(\mathrm{dt}, J=11.9,5.6 \mathrm{~Hz}, 1 \mathrm{H}), 3.61-3.45(\mathrm{~m}, 1 \mathrm{H}), 3.39(\mathrm{t}, J=$ $11.9 \mathrm{~Hz}, 1 \mathrm{H}$ ), $3.00(\mathrm{dd}, J=13.7,6.7 \mathrm{~Hz}, 1 \mathrm{H}), 2.77(\mathrm{dd}, J=13.7,6.3 \mathrm{~Hz}, 1 \mathrm{H}$ ), 2.19-1.97 (m, 2H), 1.85-1.68 (m, 1H), 1.49 (p, J=11.0 Hz, 1H).

${ }^{13} \mathrm{C}$ NMR (75 MHz, $\left.\mathrm{CDCl}_{3}\right) \delta=138.0\left(\mathrm{C}_{\mathrm{q}}\right), 129.5(\mathrm{CH}), 128.5(\mathrm{CH}), 126.6$ (CH), 89.4 (d, Jc-F $=176.2 \mathrm{~Hz}, \mathrm{CH}), 76.7$ (d, J=10.6 Hz, CH), 65.2 (d, J = $\left.11.6 \mathrm{~Hz}, \mathrm{CH}_{2}\right), 42.6\left(\mathrm{~d}, J=1.6 \mathrm{~Hz}, \mathrm{CH}_{2}\right), 38.4\left(\mathrm{~d}, J=17.1 \mathrm{~Hz}, \mathrm{CH}_{2}\right), 33.1(\mathrm{~d}, J$ $=17.5 \mathrm{~Hz}, \mathrm{CH}_{2}$ ).

${ }^{19} \mathrm{~F}$ NMR (282 $\mathrm{MHz}, \mathrm{CDCl}_{3}$ ) $\delta-169.45$ to $-169.82(\mathrm{~m})$.

$\mathrm{HRMS} \mathrm{ASAP}^{+}$calcd. for $\mathrm{C}_{12} \mathrm{H}_{16} \mathrm{OF}[\mathrm{M}+\mathrm{H}]^{+}$195.1185; found 195.1177 .

\section{Trans-2-benzyl-4-fluorotetrahydro-2H-pyran (11c)}

Prepared according to the general procedure for Oxa-Prins cyclization. Purified by flash column chromatography with a mixture of pentanediethylether (30:1) as colorless oil, (46 mg, 47\%).

IR ATR = 3062, 3028, 2949, 2861, 1496, 1454, 1365, 1337, 1258, 1068, $955,748,697 \mathrm{~cm}^{-1}$.

${ }^{1} \mathrm{H} \mathrm{NMR}\left(300 \mathrm{MHz}, \mathrm{CDCl}_{3}\right) \delta=7.41-7.16(\mathrm{~m}, 5 \mathrm{H}), 5.00(\mathrm{~d}, J=48.1 \mathrm{~Hz}, 1 \mathrm{H})$, 4.05-3.90 (m, 1H), 3.91-3.78 (m, 2H), $2.91(\mathrm{dd}, J=13.8,7.0 \mathrm{~Hz}, 1 \mathrm{H}), 2.71$ $(\mathrm{dd}, J=13.8,6.0 \mathrm{~Hz}, 1 \mathrm{H}), 2.02-1.72(\mathrm{~m}, 3 \mathrm{H}), 1.70-1.40(\mathrm{~m}, 1 \mathrm{H})$.

${ }^{13} \mathrm{C}$ NMR (75 MHz, $\left.\mathrm{CDCl}_{3}\right) \delta 138.2\left(\mathrm{C}_{\mathrm{q}}\right), 129.4(\mathrm{CH}), 128.4(\mathrm{CH}), 126.4$ $(\mathrm{CH}), 86.8(\mathrm{~d}, J=168.2, \mathrm{CH}), 72.8(\mathrm{CH}), 62.7\left(\mathrm{CH}_{2}\right), 42.7\left(\mathrm{CH}_{2}\right), 36.4(\mathrm{~d}, J=$ $20.4 \mathrm{~Hz}, \mathrm{CH}_{2}$ ), 30.9 (d, $J=20.7 \mathrm{~Hz}, \mathrm{CH}_{2}$ ).

${ }^{19} \mathrm{~F}$ NMR (282 $\mathrm{MHz}, \mathrm{CDCl}_{3}$ ) $\delta-184.9$ to $-185.5(\mathrm{~m})$.

$\mathrm{HRMS} \mathrm{ASAP}^{+}$calcd. for $\mathrm{C}_{12} \mathrm{H}_{16} \mathrm{OF}[\mathrm{M}+\mathrm{H}]^{+}$195.1185; found 195.1183 .

Trans-4-fluoro-2-(4-nitrophenyl)tetrahydro-2H-pyran (111)

Prepared according to the general procedure for Oxa-Prins cyclization, with a flow rate of $150 \mu \mathrm{L} \mathrm{min}{ }^{-1}$. Purified by flash column chromatography with a mixture of pentane-acetone (20:1) as colorless crystals, $\mathrm{mp}=102-105^{\circ} \mathrm{C},(41 \mathrm{mg}, 36 \%) \cdot{ }^{7 \mathrm{a}}$

\section{2-(2-nitrophenyl)-3,6-dihydro-2H-pyran (8m)}

Prepared according to the general procedure for Oxa-Prins cyclization, with a flow rate of $150 \mu \mathrm{L} \mathrm{min}{ }^{-1}$. Purified by flash column chromatography with a mixture of pentane-acetone (49:1) as colorless oil, (18 mg, 17\%).

IR ATR $=3080,3040,2948,2918,2839,1610,1580,1512,1346,1335$, $1176,1078,1025,897,860,790,742,656 \mathrm{~cm}^{-1}$.

${ }^{1} \mathrm{H} \mathrm{NMR}\left(300 \mathrm{MHz}, \mathrm{CDCl}_{3}\right) \delta=7.89(\mathrm{~d}, J=8.0 \mathrm{~Hz}, 1 \mathrm{H}), 7.81(\mathrm{~d}, J=7.8 \mathrm{~Hz}$, $1 \mathrm{H}), 7.64(\mathrm{t}, J=7.8 \mathrm{~Hz}, 1 \mathrm{H}), 7.42(\mathrm{t}, J=8.0 \mathrm{~Hz}, 1 \mathrm{H}), 5.98-5.87(\mathrm{~m}, 1 \mathrm{H})$, 5.86-5.83 (dd, $J=10.2,1.4 \mathrm{~Hz}, 1 \mathrm{H}$ ), 5.10 (dd, $J=10.2,3.2 \mathrm{~Hz}, 1 \mathrm{H}$ ), 4.42$4.30(\mathrm{~m}, 2 \mathrm{H}), 2.53$ (brd, $J=17.0 \mathrm{~Hz}, 1 \mathrm{H}), 2.43-2.16(\mathrm{~m}, 1 \mathrm{H})$.

${ }^{13} \mathrm{C}$ NMR $\left(75 \mathrm{MHz}, \mathrm{CDCl}_{3}\right) \delta 147.9\left(\mathrm{C}_{\mathrm{q}}\right), 138.0\left(\mathrm{C}_{\mathrm{q}}\right), 133.6(\mathrm{CH}), 128.2(\mathrm{CH})$, $128.1(\mathrm{CH}) 126.2(\mathrm{CH}), 124.4(\mathrm{CH}), 124.2(\mathrm{CH}), 71.5(\mathrm{CH}), 66.9\left(\mathrm{CH}_{2}\right)$, $32.5\left(\mathrm{CH}_{2}\right)$.

HRMS ASAP+ calcd. for $\mathrm{C}_{11} \mathrm{H}_{12} \mathrm{NO}_{3}[\mathrm{M}+\mathrm{H}]^{+}$206.0817; found 206.0823. 


\section{Trans-4-fluoro-2-(2-nitrophenyl)tetrahydro-2H-pyran (11m)}

Prepared according to the general procedure for Oxa-Prins cyclization, with a flow rate of $150 \mu \mathrm{L} \mathrm{min}{ }^{-1}$. Purified by flash column chromatography with a mixture of pentane-acetone (97:3) as colorless oil, (19 mg, 17\%).

IR ATR $=2945,2920,2867,1611,1579,1515,1439,1342,1332,1254$ $1064,1034,945,863,792,739,702 \mathrm{~cm}^{-1}$.

${ }^{1} \mathrm{H} \mathrm{NMR}\left(300 \mathrm{MHz}^{\mathrm{CDCl}} 3\right) \delta=7.89(\mathrm{~d}, J=8.0 \mathrm{~Hz}, 1 \mathrm{H}), 7.78(\mathrm{~d}, J=7.8 \mathrm{~Hz}$ $1 \mathrm{H}), 7.63(\mathrm{t}, J=7.8 \mathrm{~Hz}, 1 \mathrm{H}), 7.42(\mathrm{t}, J=7.8 \mathrm{~Hz}, 1 \mathrm{H}), 5.32(\mathrm{~d}, J=11.4 \mathrm{~Hz}$ 1H), 5.09 (d, $J=47.7 \mathrm{~Hz}, 1 \mathrm{H}), 4.05-3.97(\mathrm{~m}, 2 \mathrm{H}), 2.46$ (brt, $J=12.5 \mathrm{~Hz}$, $1 \mathrm{H}), 2.10-1.88(\mathrm{~m}, 2 \mathrm{H}), 1.83-1.59(\mathrm{~m}, 1 \mathrm{H})$.

${ }^{13} \mathrm{C}$ NMR (75 MHz, $\left.\mathrm{CDCl}_{3}\right) \delta=147.9\left(\mathrm{C}_{\mathrm{q}}\right), 137.6\left(\mathrm{C}_{\mathrm{q}}\right), 133.5(\mathrm{CH}), 128.3$ (CH), $128.1(\mathrm{CH}), 124.3(\mathrm{CH}), 86.4(\mathrm{~d}, J=170.2 \mathrm{~Hz}, \mathrm{CH}), 70.4(\mathrm{CH}), 63.4$ $\left(\mathrm{CH}_{2}\right), 38.1$ (d, $J=20.6 \mathrm{~Hz}, \mathrm{CH}_{2}$ ), 30.7 (d, $J=20.8 \mathrm{~Hz}, \mathrm{CH}_{2}$ ).

${ }^{19} \mathrm{~F}$ NMR (282 MHz, $\mathrm{CDCl}_{3}$ ) $\delta=-186.2$ to $-186.7(\mathrm{~m})$.

HRMS TOF ES ${ }^{+}$calcd. for $\mathrm{C}_{11} \mathrm{H}_{13} \mathrm{NO}_{3} \mathrm{~F}[\mathrm{M}+\mathrm{H}]^{+}$226.0879; found 226.0870.

\section{2-(3-(trifluoromethyl)phenyl)-3,6-dihydro-2H-pyran (8n)}

Prepared according to the general procedure for Oxa-Prins cyclization, with a flow rate of $150 \mu \mathrm{L} \mathrm{min}{ }^{-1}$. Purified by flash column chromatography with a mixture of pentane-ethyl acetate (99:1) as yelow oil, (7 mg, 6\%).

IR ATR = 3040, 2929, 2896, 2831, 1450, 1339, 1325, 1160, 1118, 1089 , $1070,799,701,655 \mathrm{~cm}^{-1}$.

${ }^{1} \mathrm{H}$ NMR $\left(300 \mathrm{MHz}, \mathrm{CDCl}_{3}\right) \delta=7.66(\mathrm{~s}, 1 \mathrm{H}), 7.55(\mathrm{~m}, 2 \mathrm{H}), 7.47(\mathrm{~m}, 1 \mathrm{H})$ $5.93(\mathrm{~m}, 1 \mathrm{H}), 5.76(\mathrm{brd}, J=10.4, \mathrm{~Hz}, 1 \mathrm{H}), 4.62(\mathrm{t}, J=6.9 \mathrm{~Hz}, 1 \mathrm{H}), 4.39(\mathrm{~s}$ $2 \mathrm{H}), 2.31(\mathrm{~m}, 2 \mathrm{H})$.

${ }^{13} \mathrm{C}$ NMR (75 MHz, $\left.\mathrm{CDCl}_{3}\right) \delta=143.8\left(\mathrm{C}_{\mathrm{q}}\right), 130.8\left(\mathrm{q}, J=32.2 \mathrm{~Hz}, \mathrm{C}_{\mathrm{q}}\right), 129.3$ (CH), $128.9(\mathrm{CH}), 126.6(\mathrm{CH}), 124.4(\mathrm{q}, J=3.8 \mathrm{~Hz}, \mathrm{CH}), 124.3$ (q, J = 272.2 $\left.\mathrm{Hz}, \mathrm{C}_{\mathrm{q}}\right) 124.2(\mathrm{CH}), 122.8(\mathrm{q}, J=3.9 \mathrm{~Hz}, \mathrm{CH}), 75.0(\mathrm{CH}), 66.7\left(\mathrm{CH}_{2}\right), 33.0$ $\left(\mathrm{CH}_{2}\right)$.

${ }^{19} \mathrm{~F}$ NMR (282 MHz, $\left.\mathrm{CDCl}_{3}\right) \delta=-63.1(\mathrm{~s})$.

HRMS ASAP+ calcd. for $\mathrm{C}_{12} \mathrm{H}_{12} \mathrm{OF}_{3}[\mathrm{M}+\mathrm{H}]^{+}$229.0840; found 229.0829 .

\section{Cis-4-fluoro-2-(3-(trifluoromethyl)phenyl)tetrahydro-2H-pyran} (10n)

Prepared according to the general procedure for Oxa-Prins cyclization, with a flow rate of $150 \mu \mathrm{L} \mathrm{min}{ }^{-1}$. Purified by flash column chromatography with a mixture of pentane-ethyl acetate (49:1) as colorless oil, (7 mg, 6\%).

IR ATR = 2959, 2938, 2855, 1451, 1365, 1325, 1204, 1158, 1120, 1071, $1040,983,962,801,701,669 \mathrm{~cm}^{-1}$.

${ }^{1} \mathrm{H}$ NMR $\left(300 \mathrm{MHz} \mathrm{CDCl}_{3}\right) \delta=7.64(\mathrm{~s}, 1 \mathrm{H}), 7.59-7.44(\mathrm{~m}, 3 \mathrm{H}), 4.84(\mathrm{dtt}, J$ $=49.0,10.7,4.9 \mathrm{~Hz}, 1 \mathrm{H}), 4.39(\mathrm{~d}, J=11.6 \mathrm{~Hz}, 1 \mathrm{H}), 4.31-4.17(\mathrm{~m}, 1 \mathrm{H}), 3.58$ $(\mathrm{t}, J=12.3 \mathrm{~Hz}, 1 \mathrm{H}), 2.41-2.36(\mathrm{~m}, 1 \mathrm{H}), 2.22-2.07(\mathrm{~m}, 1 \mathrm{H}), 1.97-1.79(\mathrm{~m}$, $1 \mathrm{H}), 1.79-1.65(\mathrm{~m}, 1 \mathrm{H})$.

${ }^{13} \mathrm{C}$ NMR (75 MHz, $\left.\mathrm{CDCl}_{3}\right) \delta=142.5\left(\mathrm{~d}, J=1.9 \mathrm{~Hz}, \mathrm{C}_{\mathrm{q}}\right), 131.0(\mathrm{q}, J=32.4$ $\mathrm{Hz}, \mathrm{Cq}), 129.2$ (d, J = $1.5 \mathrm{~Hz}, \mathrm{CH}), 129.1(\mathrm{CH}), 124.8$ (q, $J=3.8 \mathrm{~Hz}, \mathrm{CH}$ ), $124.2\left(\mathrm{q}, J=272.4 \mathrm{~Hz}, \mathrm{C}_{\mathrm{q}}\right) 122.8(\mathrm{q}, J=3.9 \mathrm{~Hz}, \mathrm{CH}), 89.2(\mathrm{~d}, J=177.4 \mathrm{~Hz}$, $\mathrm{CH}$ ), 77.2 (d, $J=11.6 \mathrm{~Hz}, \mathrm{CH}), 65.6\left(\mathrm{~d}, J=11.8 \mathrm{~Hz}, \mathrm{CH}_{2}\right.$ ), 40.7 (d, $J=17.4$ $\left.\mathrm{Hz}, \mathrm{CH}_{2}\right), 33.0\left(\mathrm{~d}, J=17.7 \mathrm{~Hz}, \mathrm{CH}_{2}\right.$ ).

${ }^{19} \mathrm{~F}$ NMR (282 MHz, $\mathrm{CDCl}_{3}$ ) $\delta=-63.1(\mathrm{~s}),-170.5$ to $-170.8(\mathrm{~m})$.

HRMS ASAP ${ }^{+}$calcd. for $\mathrm{C}_{12} \mathrm{H}_{13} \mathrm{OF}_{4}[\mathrm{M}+\mathrm{H}]^{+} 249.0903$; found 249.0896

Trans-4-fluoro-2-(3-(trifluoromethyl)phenyl)tetrahydro-2H-pyran (11n)

Prepared according to the general procedure for Oxa-Prins cyclization, with a flow rate of $150 \mu \mathrm{L} \mathrm{min}{ }^{-1}$. Purified by flash column chromatography with a mixture of pentane-acetone (49:1) as colorless oil, (21 mg, 17\%).

IR ATR $=2956,2867,1450,1431,1370,1326,1256,1205,1161,1116$, $1069,874,799,700,659 \mathrm{~cm}^{-1}$.

${ }^{1} \mathrm{H}$ NMR (300 MHz, $\left.\mathrm{CDCl}_{3}\right) \delta=7.65(\mathrm{~s}, 1 \mathrm{H}), 7.55-7.43(\mathrm{~m}, 3 \mathrm{H}), 5.10(\mathrm{~d}, J=$ $47.8 \mathrm{~Hz}, 1 \mathrm{H}), 4.81$ (dd, $J=11.8,2.3 \mathrm{~Hz}, 1 \mathrm{H}), 4.03(\mathrm{dd}, J=9.6,3.1 \mathrm{~Hz}, 2 \mathrm{H}$ ),
2.28-2.12 (m, 1H), 2.11-1.80 (m, 3H), 1.72 (ddd, $J=14.3,11.8,2.2 \mathrm{~Hz}$, $1 \mathrm{H})$.

${ }^{13} \mathrm{C}$ NMR (75 MHz, CDCl $) \delta=143.4\left(\mathrm{C}_{\mathrm{q}}\right), 10.9\left(\mathrm{q}, J=32.0 \mathrm{~Hz}, \mathrm{C}_{\mathrm{q}}\right), 129.2$ $(\mathrm{CH}), 129.0(\mathrm{CH}), 124.5(\mathrm{q}, J=3.7 \mathrm{~Hz}, \mathrm{CH}), 124.3\left(\mathrm{q}, J=272.2 \mathrm{~Hz}, \mathrm{C}_{\mathrm{q}}\right)$ $122.7(\mathrm{q}, J=3.8 \mathrm{~Hz}, \mathrm{CH}), 86.7(\mathrm{~d}, J=169.3 \mathrm{~Hz}, \mathrm{CH}), 73.6(\mathrm{CH}), 63.2\left(\mathrm{CH}_{2}\right)$, $38.8\left(\mathrm{~d}, J=20.2 \mathrm{~Hz}, \mathrm{CH}_{2}\right), 30.6\left(\mathrm{~d}, J=20.7 \mathrm{~Hz}, \mathrm{CH}_{2}\right)$.

${ }^{19} \mathrm{~F} \mathrm{NMR} \mathrm{(282} \mathrm{MHz,} \mathrm{CDCl}_{3}$ ) $\delta=-63.1(\mathrm{~s}),-186.2$ to $-186.7(\mathrm{~m})$.

HRMS ASAP+ calcd. for $\mathrm{C}_{12} \mathrm{H}_{12} \mathrm{OF}_{4}[\mathrm{M}]+248.0824$; found 248.0834 .

\section{Acknowledgment}

A.T.A. is grateful to CONACYT-Mexico for the grant 740484

\section{References}

(1) a) Olier, C.; Kaafarani, M.; Gastaldi, S.; Bertrand, M. P. Tetrahedron, 2010, 66, 413. b) Greco, S. J.; Fiorot, R. G.; Lacerda, V. J.; Bezerra dos Santos, R. Aldrichimica Acta 2013, 46, 59. c) Han, X.; Peh, G. R.; Floreancig, P. E. Eur. J. Org. Chem. 2013, 1193. d) Pastor, I. M.; Yus, M. Curr. Org. Chem. 2017, 17, 925. e) Subba Reddy, B. V.; Nair, P. N.; Antony, A.; Lalli, C.; Grée, R. Eur. J. Org. Chem. 2017, 1805.

(2) a) Carballo, R. M.; Valdomir, G.; Purino, M.; Martín, V. S.; Padrón, J. I. Eur. J. Org. Chem. 2010, 2304. b) Bondalapati, S.; Reddy, U. C.; Kundu, D. S.; Saikia, A. K. J. Fluorine Chem. 2010, 131, 320. c) Subba Reddy, B. V.; Borkar, P.; Chakravarthy, P. P.; Yadav, J. S.; Gree, R. Tetrahedron Lett. 2010, 51, 3412. d) Chio, F. K.; Warne, J.; Gough, D.; Penny, M.; Green, S.; Coles, S. J.; Hursthouse, M. B.; Jones, P.; Hassall, L.; McGuire, T. M.; Dobbs, A. P. Tetrahedron, 2011, 67, 5107.

(3) a) Cloninger, M. J.; Overman, L. E. J. Am. Chem. Soc. 1999, 121, 1092. b) Barry, C. S. J.; Crosby, S. R.; Harding, J. R.; Hughes, R. A.; King, C. D.; Parker, G. D.; Willis, C. L. Org. lett. 2003, 5, 2429. c) Yadav, J. S.; Reddy, M. S.; Rao, P. P.; Prasad, A. R. Tetrahedron Lett. 2006, 47, 4397. d) Yadav, J. S.; Krishana, G. G.; Kumar, S. N. Tetrahedron 2010, 66, 480. e) Vintonyak, V. V.; Maier, M. E. Org. Lett. 2008, 10, 1239.

(4) a) Yadav, J. S.; Subba Reddy, B. V.; Kumar, G. G. K. S. N.; Reddy, G. M. Chem. Lett. 2007, 36, 426. b) Miranda, P. O.; Carballo, R. M.; Martín, V. S.; Padrón, J. I. Org. Lett. 2009, 11, 357-360. c) Rychnovsky, S. D.; Yang, G.; Hu, Y.; Khire, U. R. J. Org. Chem. 1997, $62,3022$.

(5) a) Dobbs, A. P.; Martinović, S. Tetrahedron Lett. 2002, 43, 7055. b) Dobbs, A. P.; Guesné, S. J. J.; Martinović, S.; Coles, S. J.; Hursthouse, M. B. J. Org. Chem. 2003, 68, 7880. c) Dobbs, A. P.; Guesné, S. J. J.; Hursthouse, M. B.; Coles, S. J. Synlett 2003, 1740. d) Díez-Poza, C.; Barbero, H.; Diez-Varga, A.; Barbero A. In Progress in Heterocyclic Chemistry, Vol. 30; Gribble, G. W.; Joule, J. A., Ed.; Elsevier, 2018, 13.

(6) a) Kishi, Y.; Nagura, H.; Inagi, S.; Fuchigami, T. Chem. Commun. 2008, 3876. b) Kishi, Y.; Inagi, S.; Fuchigami, T. Eur. J. Org. Chem. 2009, 103. c) Batista, P. K.; de O. Ferreira, J. M. G.; Silva, F. P. L.; Vasconcellos, M. L. A. A.; Vale, J. A. Molecules, 2009, 24, 2084. d) Wang, W.; Shao, L.; Cheng, W.; Yang, J.; He, M. Catal. Commun. 2008, 9, 337.

(7) a) Launay, G. G.; Slawin, A. M. Z.; O'Hagan, D. Beilstein J. Org. Chem. 2010, 6, 41. b) Parchinsky, V.; Shumsky, A.; Krasavin, M. Tetrahedron Lett. 2011, 52, 7157. c) Parchinsky, V.; Shumsky, A.; Krasavin, M. Tetrahedron lett. 2011, 52, 7161.

(8) Hirai, K.; Takeda, R.; Hutchison, J. A.; Uji-i, H. Angew. Chem. Int. Ed. 2020, 59, 5332; Angew. Chem. 2020, 132, 5370.

(9) a) Hughes, D. L. Org. Process Res. Dev. 2018, 22, 13. b) Akwi, F. M.; Watt, P. Chem. Commun., 2018, 54, 13894. c) Bogdan, A. R.; Organ, M. G. In Top. Heterocycle. Chem. Vol. 56, Sharma, U. K.; Van der Eycken, E. V., Springer, Cham 2018, 319. d) Brandão, P.; Pineiro, M.; Pinho e Melo, T. M. V. D. Eur. J. Org. Chem. 2019, 7188.

(10) a) Bagley, M. C.; Fusillo, V.; Jenkins, R. L.; Lubinu, M. C.; Mason, C. Beilstein J. Org. Chem. 2013, 9, 1957. b) Tambarussi, B. P.; Noël, T.; 
Wang, Q.; Hessel, V. Tetrahedron Lett. 2014, 55, 2090. c) Martin R. E.; Morawitz, F.; Kuratli, C.; Alker, A. M.; Alanine, A. I. Eur. J. Org. Chem. 2012, 47.

(11) a) Giovine, A.; Musio, B.; Degennaro, L.; Falcicchio, A.; Nagaki, A.; Yoshida, J-i.; Luisi, R. Chem. Eur. J. 2013, 19, 1873 b) Tsoung, J.; Bogdan, A. R.; Kantor, S.; Wang, Y.; Charaschanya, M.; Djuric, S. W. J. Org. Chem. 2017, 82, 1073.

(12) Baumann, M.; Baxendale, I. R.; Kirschning, A.; Ley, S. V.; Wegner, J. Heterocycles, 2011, 82, 1297. b) Drop, M.; Bantreil, X.; Grychowska, K.; Mahoro, G. U.; Colacino, E.; Pawłowski, M.; Martinez, J.; Subra, G.; Zajdel, P.; Lamaty, F. Green Chem., 2017, 19, 1647.

(13) a) Osorio-Planes, L.; Rodríguez-Escricha, C.; Pericàs, M. A. Catal. Sci. Technol. 2016, 6, 4686. b) Riva, E.; Rencurosi, A.; Gagliardi, S.; Passarella, D.; Martinelli, M. Chem. Eur. J. 2011, 17, 6221.
(14) a) York, M. Tetrahedron lett. 2011, 52, 6267. b) Fukuyama, T.; Fujita, Y.; Rashid, M. A.; Ryu, I. Org. Lett. 2016, 18, 5444. c) Hoffmeyer, P.; Schneider, C. Eur. J. Org. Chem. 2019, 5326.

(15) a) Dobbs, A. P.; Guesné, S. J. J. Synlett 2005, 2101. b) Colin, O.; Greck, C.; Prim, D.; Thomassigny, C. Eur. J. Org. Chem. 2014, 7000. c) Subba Reddy, B. V.; Chaya, D. N.; Yadav, J. S.; Grée, R. Synthesis 2012, 44, 297.

(16) Kazuo, K.; Tsutomu, K.; Junji, M. PTC Int. Apl. WO 2010131717, 2010.

(17) Wang, X.; Wang, Y.; Du, D.-M.; Xu, J. J. Mol. Catal. A: Chem., 2006 255, 31. b) Harikrishnan, A.; Gnanasekaran, R.; Ramanathan, C. R. ChemistrySelect 2016, 1, 3022.

(18) Jaber, J. J.; Mitsui, K.; Rychnovsky, S. D. J. Org. Chem. 2001, 66, 4679. b) Okoromoba, O. E.; Hammond, G. B.; Xu, B. Org. Lett. 2015, 17,3975 . 